\title{
Hanford faces up to its nuclear hangover
}

Richland, Washington. The Hanford Engineering Works in Washington state, as the most notorious environmental wasteland in the United States, has an infamous reputation to live down to. But in reality, the most striking facet of the 530 -square-mile site is its serenity.

The blue-collar members of the 12,000 strong Hanford workforce are out in the sunshine, tidying up. The main processing buildings - disused since Hanford withdrew from its role in the nuclear weapons programme in 1990 - are being methodically stripped down to a condition in which they will remain contaminated, but can be cheaply maintained.

Contamination from Hanford ground water puts 6,000 curies of radiation into the Columbia river each year - about the same as it brings down from lands upstate and in Canada. The Hanford tanks are hidden underground, but neatly labelled.

Plutonium production - Hanford's main task during the Cold War - produced large volumes of radionuclides dissolved in nitric acid. The much smaller weapons programmes of Britain and France wisely kept such acid in stainless-steel tanks. But the Hanford engineers chose to turn the acid into alkali so that it could be kept in cheaper, carbon-steel tanks. They have been struggling with the consequences ever since. The tanks are Hanford's greatest headache: 177 giant underground vestibules filled with a varied and highly radioactive cocktail of liquid, paste and precipitate.

Many of the 149 older tanks, which have just a single shell of steel, have leaked at some stage, losing perhaps one million gallons of waste.

Ferrocyanide - a compound with an unfortunate tendency to explode at high temperature - was added to remove radioactive solids by precipitation so that less radioactive liquid could be dumped in the soil. Contents were mixed in unknown ways as waste was transferred from tank to tank. Chemical reactions cause some tanks to bubble hydrogen and other gases, and make it hard to keep track of the contents.

\section{Not so scary}

But the situation in the tanks is not quite as scary as it sounds. All the liquid waste is due to be moved to the 28 newer, double-shell tanks (leaving behind precipitate and sludge) which have no history of leaks. According to Ron Lerch, deputy director of tank remediation at Hanford, the ferrocyanide has decomposed completely in some - maybe all - of the tanks to which it was added.

Furthermore, with 99 per cent of the 200 million curies of radioactivity in the tanks coming from short-lived isotopes of cae- sium and strontium, they will lose half of their potency in 30 years. (In 800 years, only one curie from these two isotopes - plus 125,000 curies from other, long-lived radionuclides - would remain.)

Another pressing issue on the site is the fate of 2,000 tonnes of spent nuclear fuel now corroding gently away in basins of water next to one of the disused reactors by the Columbia river. Under an accelerated $\$ 700$-million programme, the fuel will be removed at the end of next year, dried off and stored in a 'temporary' vault.

Another accelerated programme will

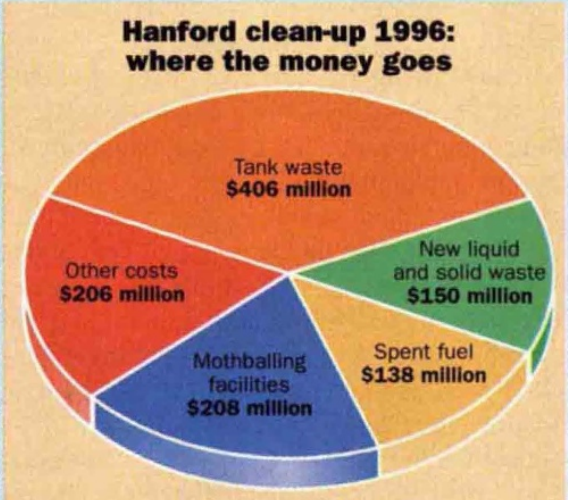

mothball B Plant, one of the five huge canyon buildings at Hanford. The mothballing will be complete two years from now, and will cut the annual cost of maintenance from \$20 million to \$1 million.

But 150 million curies of extracted caesium and strontium and their waste products will remain next door in pools - from which the intense radiation emits an eerie, blue light - and in need of constant attention.Still more is stored in organic solvents. And three-quarters of a million curies lurk in several large air filters. "We don't know what to do with them," concedes Bob Heineman, B Plant manager. Four other canyons at Hanford house similar problems, exacerbated by the presence of large amounts of plutonium.

Although many question its efficiency, a good deal of technically straightforward clean-up is therefore now taking place. It is true that no radionuclides are leaving the site. But progress is being made in containing what is already there. The real crisis concerns not the present but the future.

Under the 1993 version of the so-called Tri-party Agreement between the Department of Energy (DoE), Environmental Protection Agency and Washington state, the department is obliged to pursue expensive and technically dubious clean-up strategies.

Top of the list is the proposed vitrification of the entire contents of the tanks, for underground storage off the site and out of the state. The National Research Council
(NRC) has said that there is neither a technical nor a financial basis for this decision.

Three problems stand out. It is not known whether 99 per cent of the waste can be retrieved from the sludge-filled tanks, as promised. How much of the retrieved waste would be suitable for vitrification is also unknown. And there is nowhere to put the resulting glass: even if planned underground stores are built, they would not be large enough for all the Hanford waste.

But vitrification is politically attractive, because it creates jobs, meets regulatory requirements and shows that something is being done. Many of the 'stakeholders' are tired of endless study of the problem, and want to see 'action'. Whenever the DoE talks about research, says Don Wodrich of its Richland office, "the stakeholders say "we've been hearing that for years". He adds: "Until we start vitrifying some of the tank waste, I don't think we can have meaningful discussions about the rest."

\section{Demonstration plants}

In April, the DoE published an environmental impact statement, confirming its decision to build two 'demonstration' vitrification plants at Hanford to process lowlevel waste from the tanks, and a full-scale plant to vitrify the rest. The cost was estimated at between $\$ 32$ billion and $\$ 42$ billion. Many scientists hope that fiscal reality and technical infeasibility will squeeze this plan out of existence. Last month, an NRC panel recommended that it be shelved.

The Tri-party Agreement also calls for extensive 'pump and treat' of groundwater at Hanford - a strategy whose main advantage is psychological (see page 378). As for the defunct reactors by the river, the state and the stakeholders want them away from the water table. The plan is to dig up each reactor core, encased in 15,000 tonnes of concrete, and drag it uphill.

This bold plan of action calls for four transporters each able to carry 16,400 tonnes - twice the capacity of the largest such cart in the world, used by NASA for space shuttle launches - and the construction of a road 25 miles long that can carry such a vehicle, to lift the blocks $140 \mathrm{ft}$ up to the dumping ground a couple of miles away at a shallow gradient. A report prepared for the US Senate called the scope and uncertainty of this proposal "staggering".

Tom Grumbly, the under-secretary for energy, points out that the department had to reach agreements, such as that at Hanford, in a hurry to fend off legal action. "There's going to be plenty of room for us to change strategy as we move forward," he says. "But one of the big criticisms of the programme is that it has stood in place too long. We need to get going." $\quad$ C. $\mathbf{M}$. 